\title{
航空機LiDARによる森林計測手法
}

\author{
山本一清 \\ 名古屋大学大学院 生命農学研究科 ( ₹464-8601 愛知県名古屋市千種区不老町)
}

\section{Forest Measurement Technique Using Airborne LiDAR}

\author{
Kazukiyo YAMAMOTO \\ Graduate School of Bioagricultural Sciences, Nagoya University, Furo-cho, Chikusa-ku, Nagoya, Aichi 464-8601
}

(Received January 20, 2016)

\begin{abstract}
As world-wide concern for the global warming continues to grow, the roles of sinks and reservoirs on greenhouse gas in forests are receiving greater attention. To evaluate these roles in forests, we require detailed accurate information on the amount and structure of forest resources, especially aboveground biomass. Therefore, the importance of airborne LiDAR (Light Detection and Ranging) is increasing as a tool to obtain such information. This paper reviews the primary techniques for evaluating forest resources using airborne LiDAR.
\end{abstract}

Key Words: Airborne LiDAR, Forest, Tree height

1. はじめに

日本では森林簿といわれる森林資源状況を記載した帳 簿が各都道府県で管理され, 行政方針の立案や林業事業 体等による森林の現況把握の基礎的情報として用いられ ている ${ }^{1-3)}$. これらは, 京都議定書で規定される森林成 長による $\mathrm{CO}_{2}$ 吸収量算定の情報源としても用いられる など，その重要性は近年益々高くなっている，その一方 で, 既存の森林簿情報と実際の森林現況に乘離があるこ とは周知の事実でもある ${ }^{3)}$.

森林現況を調査する取組みとして, 林野庁は1999年か ら5年周期で森林資源モニタリング調査 (2009年度から森 林生態系多様性基礎調査に引き継がれている)が実施さ れているが, これは広域性を持つものの, 系統的に配置 されたポイント上でのサンプル調査にとどまっており, 森林簿や森林計画図といった面的な情報の更新に応用さ れる期待は低( ${ }^{3)}$ とされる。国内人工林は既に育成の段 階から間伐を行いつつ木材を搬出し, 利用していく収穫 の段階に達した ${ }^{4)}$ とされるなか, 今後増々森林簿や森林 計画図といった面的な情報の精度向上と継続的な更新が 必要性となる。

これら森林情報の精度を高めるには，広域を対象に， より詳細かつ正確にモニタリングを行うことが望ましい が，これらを現地調査のみで対応するのは困難である。 そこで，近年広域を対象により詳細かつ正確にモニタリ ングを行う技術として航空機LiDARが注目さている，既 に岐阜県 ${ }^{5}$ や佐賀県 ${ }^{6}$ などのように，県内森林域の航空 機LiDAR観測を行い森林管理に利用するなど，急速に利
用が拡大している。そこで，本稿では2章で航空機 LiDARによる森林計測手法の概要を，また3章・4章では 詳細と具体例を紹介し，5章はまとめとする.

\section{2. 航空機LiDARによる森林計測の概要}

航空機LiDAR (Light Detection and Ranging)は, リモー トセンシング技術の一種で，航空機から地上に向けて レーザーを照射し，その反射地点の地表面や地物の3次 元位置情報を直接的に取得する測量技術である ${ }^{7,8)}$ 。航 空機LiDARによる森林計測は，すでに1970年代にはプ ラットホームの直下をライン状に計測する航空機レー ザープロファイラーを用いた実験が主に北米において実 施されていた. 1990年代に入ると，このレーザープロ ファイラーはレーザースキャナー (Laser Scanner: LS)に 置き換えられ，また航空機の位置，加速度，角速度をり アルタイムで記録できる GNSS (汎地球測位航法衛星シ ステム)・IMU(姿勢計測装置)と連動させて計測するこ とにより，面的な広がりでの高精度の3次元計測が可能 となった ${ }^{8,9)}$. 現在, 航空機LiDARとしては, この航空 機レーザースキャナー (Airborne Laser Scanner: ALS)が一 般的であり，以下航空機LiDARはALSを指すこととす る。

現在，航空機LiDARに搭載されるLS では，レーザー 光の照射頻度は数百 $\mathrm{kHz}$ にまで達している，航空機LiDAR におけるレーザー照射は, 航空機の機体方向と直 行する方向に一定の振幅で照射されるため，レーザー光 の地上照射密度 $\left(\rho: / \mathrm{m}^{2}\right)$ は, レーザー光の照射頻度 $(F: \mathrm{Hz})$, 
航空機の速度 $(V: \mathrm{m} /$ 秒 $)$ 及び対地高度 $(H: \mathrm{m})$, レーザー スキャナーのスキャン角 ( $\theta$ : 度)から (Fig. 1),

$$
\rho=\frac{F}{2 V H \tan \frac{\theta}{2}}
$$

となる ${ }^{10)}$.

この航空機LiDARによる森林計測手法には, 大きく分 けて2つのアプローチがあるが，どちらの手法を用いる べきかは式(1)の地上照射密度に依存する。この2つのア プローチのうちの一つは, 個々の立木を抽出して解析す る方法(Individual tree delineation approach)であり，もう 一方はプロットレベルで林冠(Fig. 2)内におけるレー ザー反射点の分布に由来する統計量などにより解析する 方法(Laser canopy height distribution approach)である ${ }^{11-13)}$. 一般に, 前者の方法は比較的高い地上照射密度で観測さ れた場合, 後者の方法は逆に比較的低い地上照射密度で 観測された場合に用いられる解析手法である。これは, Fig. 3(a)のように, 地上照射密度が高い場合は個々の立 木の樹冠形状を精密に再現することができるが, Fig. 3 （b）のように地上照射密度が低い場合は, それを正確に 再現することは困難である，具体的には，立木個体が抽 出可能な地上照射密度としては, $1 \mathrm{~m}^{2}$ たり 4 点〜 10点 ${ }^{14,15)}$

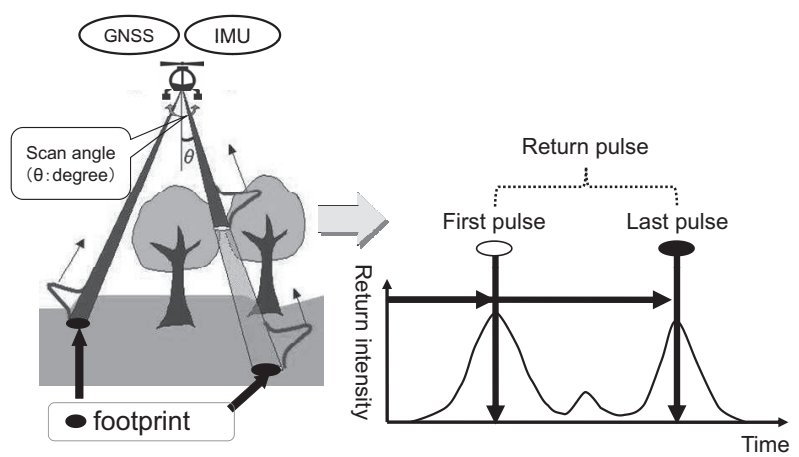

Fig. 1 Overview of airborne LiDAR and return pulses.

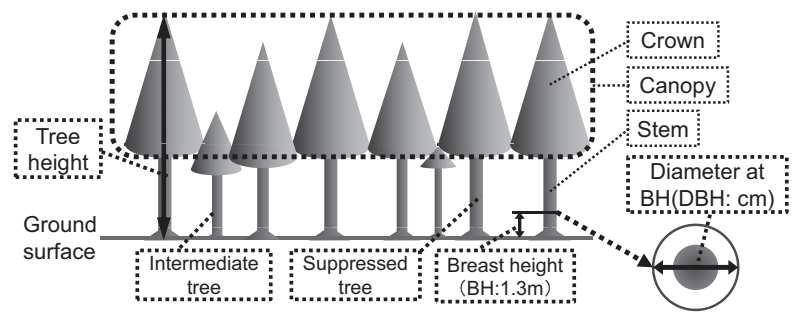

Fig. 2 Overview of forest structure.

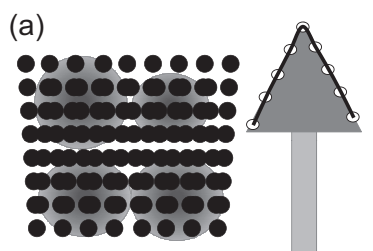

(b)

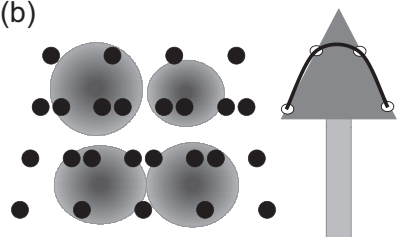

Fig. 3 Laser pulse density ((a) high density, (b)low density) and crown shape.
程度といわれている。実際に日本のスギ・ヒノキの人工 林などにおいても，レーザー光の地上照射密度を変化さ せた場合に $3 \sim 5$ 点 $/ \mathrm{m}^{2}$ 以下で樹木個体抽出率の急激な低 下が指摘9)されており，前者の方法を用いる場合は現実 的には $1 \mathrm{~m}^{2}$ あり 6 点以上の地上照射密度が望ましいと 考えられる。一方，後者の方法を用いる場合では $1 \mathrm{~m}^{2}$ 的 たり $0.1 〜 0.5$ 点程度でも有効であるとされている ${ }^{14,16,17)}$. 高い地上照射密度による観測の方が，様々なアプローチ をとることが可能であり，林冠表面の形状を精緻に再現 できる，その一方，地上照射密度を上げるためには，式 1の右辺の分母を小さくする必要がある。この分母は, 単位時間 (1秒)当たりの観測面積に相当し, これを小さ くすれば観測時間が増大するため, 観測に要するコスト も増大することになる ${ }^{18)}$. しかし，前者の方法では，後 述するように，個々の樹木の樹高，そして完全ではない が本数(密度)を直接的に(推定式等を介さず)推定するこ とが可能であるという利点がある.

\section{3. 個々の立木を抽出して解析する方法}

航空機LiDARにより得られるデータ(以下, LiDAR データとする)は，基本的には林冠表面及び地表面の3次 元情報である (Fig. 4)，従って，高密度での地上照射に より直接計測可能な情報は，林冠表面を形成する個々の 立木の樹高と，林冠表面に出ている樹冠の大きさであ $ろ^{10)}$ 。また，立木本数は抽出された個々の立木の合計数 として算出される。一方, どれ程高密度に地上照射しよ うとも，現実的には胸高直径等の樹幹形状 (Fig. 2)を航 空機LiDARデータから直接計測することは不可能である (Fig. 4)。これは，空中から照射されるレーザーの大部 分は林冠表面で反射され, 透過したレーザー光もそれよ りも下部の葉・枝等で反射し，胸高位置にまで到達する 割合は少なく ${ }^{10)}$, 直径数 $\mathrm{cm}$ 数十 $\mathrm{cm}$ の樹幹断面を復元 できるほどの計測データは得られないためである。した がって, 胸高直径や材積等の推定おいては, 現地調査に より得られた樹高と胸高直径や材積間の関係式，または 航空機LiDARデータから計測可能な樹高や樹冠の大きさ 等の推定值と現地調査による胸高直径や材積等の実測值 から予測式を求めて利用するなどの方法が用いられてい る $^{19-21)}$.

樹高の測定は, 一般的に各パルスの3次元座標 $(x, y, z)$ 及び付随する情報（FPかLPかを示す数值やパルスの反射

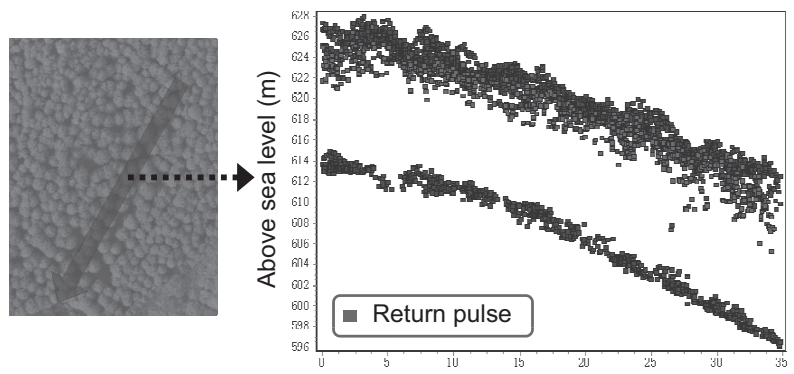

Fig. 4 Vertical sectional view of return pulses. 
強度等)で構成されるLiDARデータから，一般的に以下 のような手順で計測される。

(1)DSM (Digital Surface Model) 及びDTM (Digital Terrain Model)の作成 (Fig. 5)

(2)DSMとDTMの差分としてDCHM (Digital Canopy Height Model)を作成 (Fig. 6)

(3)DCHMまたはDSMから各立木の樹頂点（樹木の梢端位 置) 及び樹冠を抽出し, 樹頂点におけるDCHMの值を樹 高とする (Fig. 6)

まず，(1)においては，航空機LiDARデー夕から， DSM及びDTMなどのラスターデータ（行と列の格子状に 並んだメッシュから構成されるデータ)化が行われる。

この場合のメッシュサイズ (1辺の長さ) は, 多くの研 究 $^{10,19-21)}$ で10 50 cmが一般的に利用されている. 当然, メッシュサイズは地上照射密度を考慮して決定されるべ きである，例えば，地上照射密度が4点/ $\mathrm{m}^{2}$ の場合は, メッシュサイズを50 cmとすれば, ほぼすべてのメッ シュにLiDARデータが存在することが期待できるが, $50 \mathrm{~cm}$ 未満ではLiDARデータが存在しないメッシュが増 加することとなる. 航空機LiDARデータが存在しない メッシュは, 通常周囲の航空機LiDARデータから補間に より推定されることとなる。一方, 大部分のメッシュ内

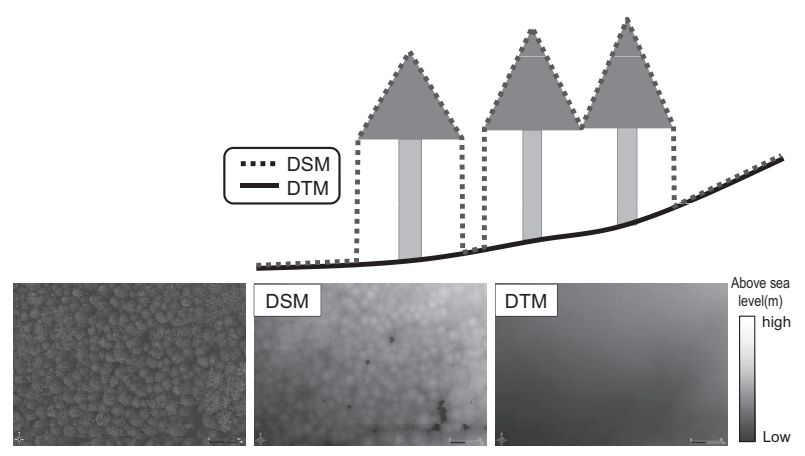

Fig. 5 Overview of DSM (Digital Surface Model) and DTM (Digital Terrain Model).

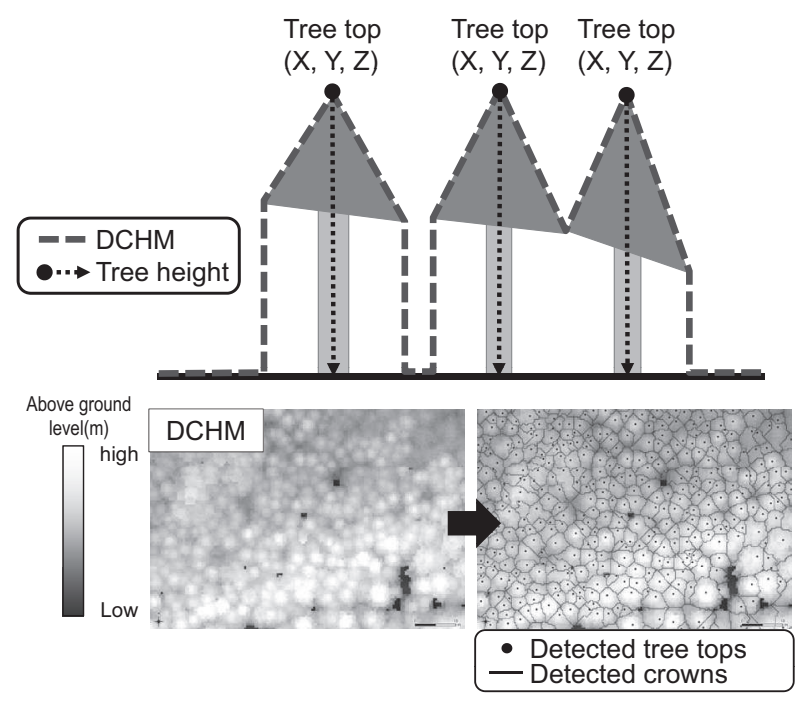

Fig. 6 Estimation of tree height by DCHM and position of detected tree top.
に複数の航空機LiDARデータが存在する場合は，一般的 にDSMについては各メッシュ内のファーストパルス (FP)の最大標高值が 9,22), DTMについてはラストパルス (LP)の最低標高值が用いられる。しかし，DTMにおい ては，その中には幹・枝・下層植生等の地表面の上部で 反射されたパルスも含まれると考えられる。そのため, LPデータから地表面で反射されたパルスのみを抽出す る方法が幾つも提案されている ${ }^{23-25)}$ 。 また，そうして抽 出された地表面で反射されたパルスは，一般に林冠表面 より遥かに低い密度となってしまうため, LPデー夕の みではDTMに多くの航空機LiDARデータが存在しない メッシュが生じる。国内においては，老齢な人工林では 地表面で反射されるパルスの割合は20３0\% ${ }^{9)}$ ，それよ りも若い人工林では1〜 8\%程度であり，また樹種により その割合も異なることが報告されている ${ }^{26)}$. そのため, DTMの作成においては，通常抽出された地表面で反射 されたパルスのデータを利用して，補間によりDTMを 作成する必要がある。

一方，(3)においては，DSMやDCHMへのLocal Maximum Filtering (LMF) 処理 (Fig. 7)により樹頂点を抽出し, これをシード点としてDSMやDCHMからWatershed法や Valley Following法などの方法により各樹冠を抽出する手 法がよく用いられる ${ }^{19,20,27)}$ 。ただし，いずれの手法にお いても介在木や被圧木 (Fig. 2) 等の抽出が現状では困難 であること ${ }^{28,29)}$ や，樹冠サイズが過小推定となる ${ }^{22}$ 問題 点が指摘されている. しかし, 少なくとも抽出可能な立 木の樹高推定に拈いては高い計測精度が数多く報告され ている ${ }^{19,22,28)}$.

ここでは, 筆者らが東京大学大学院農学生命科学研究 科附属演習林生態水文学研究所内の七ノキ人工林におい て実施した研究例を紹介する。

航空機LiDARデータから筆者らが開発した解析システ ムLiDAS (LiDAR Data Analysis System) ${ }^{28)}$ (Fig. 7及びFig. 8) により立木個体を抽出すると，Fig. 9に示したように， 通常抽出樹頂点位置と現地測量により得られた立木位置 は完全には一致しない27,28)。これには, 現地測量と航空 機LiDAR観測における測定誤差や測定精度の差異, Fig. 2(b)のように立木の実樹頂点にレーザー計測点が 存在しなかった場合, 立木個体の傾斜 ${ }^{10)}$ の影響など複数 の要因が考えられる。そのため, 検出木(実立木と同定 できた樹頂点が存在した場合)及び未検出木(実立木と同 定できた樹頂点が存在しない場合)の確認においては， 現地調査における樹冠サイズの測定結果を利用する ${ }^{28)}$,

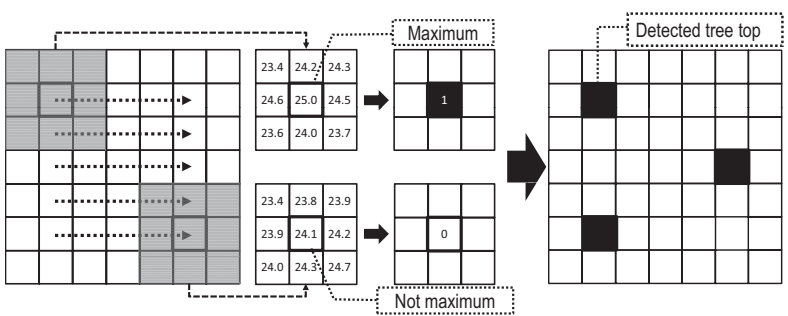

Fig. 7 Detection of tree tops by LMF(Local Maximum Filtering). 


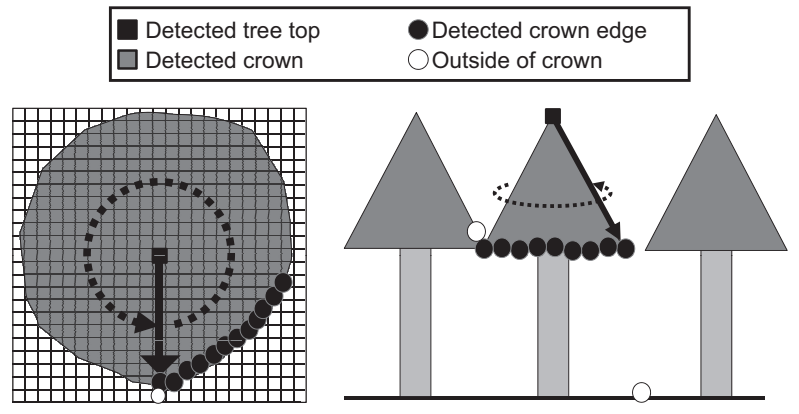

Fig. 8 Segmentation method of tree crowns in LiDAS.

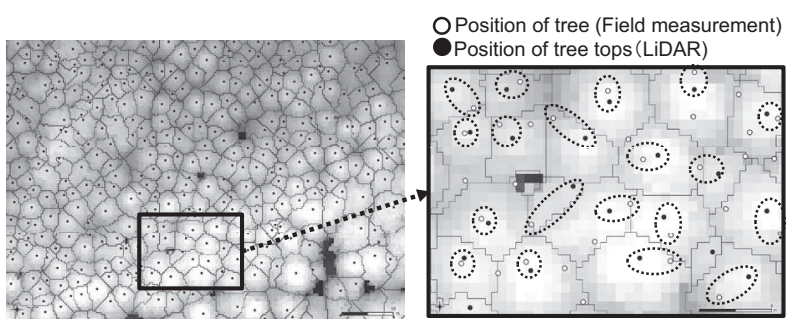

Fig. 9 Imputation of detected tree top ( ) to tree position (O) (Field measurement).

または一定の闇值を設定する いられている。 たた，検出木については，樹頂点の地上 高 (推定樹高) $(X: \mathrm{m})$ は現地で計測した実測樹高 $(Y: \mathrm{m})$ と ほぼ一致し(Fig. 10(a)), 平均二乗誤差 (RMSE) も $1.0 \mathrm{~m}$ 以下と高い測定精度を示した。

一方, Fig. 10(b)に示したように介在木や被圧木等の 比較的サイズの小さい立木において未検出木が比較的多 く存在した。抽出された森林全体の資源量として積算す ると過少推定となるが, 未検出木は介在木や被圧木 (Fig. 2) がほとんどであるため森林全体の資源量への影 響は比較的小さいと考えられる ${ }^{20)}$.

\section{4. プロットレベルの解析法}

プロットレベルの解析においては，対象とするエリア 内における航空機LiDARデータの3次元分布から各種の 指標 (以下, 航空機LiDAR指標とする)を算出し, 資源量 等の目的とする諸量の広域推定を行う手法である。推定
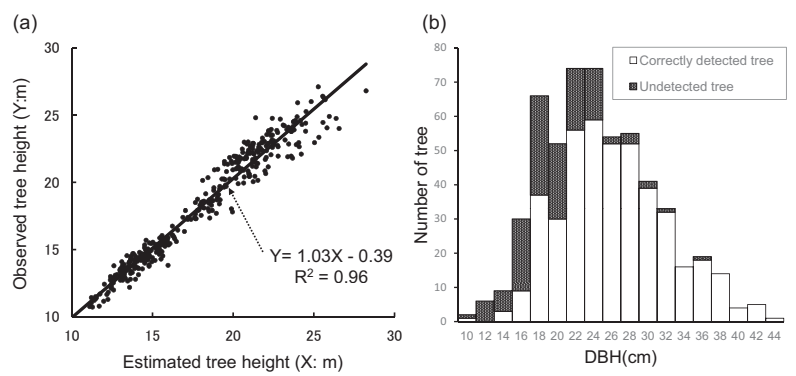

Fig. 10 Relationship between estimated and observed tree heights (a), and size distribution of correctly detected and undetected trees in DBH (b).
においては，標本調査による現地データと航空機LiDAR 指標の関係性を様々なモデル(線形回帰・重回帰・対数 重回帰・乗法など)により定式化し，そのモデル式を用 いて広域推定を行う手法が一般的である ${ }^{11,30,31)}$ 。この手 法で用いられる航空機LiDAR指標の代表的なものとして は，最大及び平均林冠高，林冠高パーセンタイル (Canopy Height Percentile (CHP): m) やレーザー透過率 (Laser Penetration Ratio (LPI): \%)等があり，それぞれ次のよう に求められる。

まず，点群データ $(x, y, z)$ の座標 (反射位置の標高) からDTMの $(x, y)$ 座標における標高 $\left(\mathrm{DTM}_{(\mathrm{x}, \mathrm{y})}\right.$ : m) 差し 引き, 全点群データの $\mathrm{z}$ 座標を地面からの高度 $(\mathrm{AGL}=$ $\left.z-\mathrm{DTM}_{(\mathrm{x}, \mathrm{y})}: \mathrm{m}\right)($ Fig. 11) に変換する. 次に, 変換した点群 データ $(x, y, \mathrm{AGL})$ を, 地面から一定の高さに閾值(海 外の文献などでは $2 \mathrm{~m} ゙$ よく使われる)を設定し，それ 以上のAGLの点を林冠点群 (Fig. 11のA), それ以下を地 面点群 (Fig. 11のB) として分離する.この林冠点群の AGLの平均及び最大值が最大平均高及び平均林冠高と なる。さらに，林冠点群において，最小のAGL（たた し，上記間值以上）を持つ点から最大のAGLを持つ点に 向かって，相対累積頻度分布を計算する (Fig. 11のC). このデータを用い，相対累積頻度が一定のパーセンタイ ル $(0 \%, 10 \%, 20 \%, \cdots, 90 \%)$ となるAGLがCHPとな る。一方，LPIは，地面反射点数 $\div$ 全反射点数 $\times 100(\%)$ のことで，照射されたレーザーが，林冠を透過する割合 を指す。

ここでも，一例として筆者らが東京大学大学院農学生 命科学研究科附属演習林生態水文学研究所内の七ノキ人 工林において実施した研究例 ${ }^{32}$ を紹介する.

Fig.12(a)は，現地調査により測定した林内の相対照

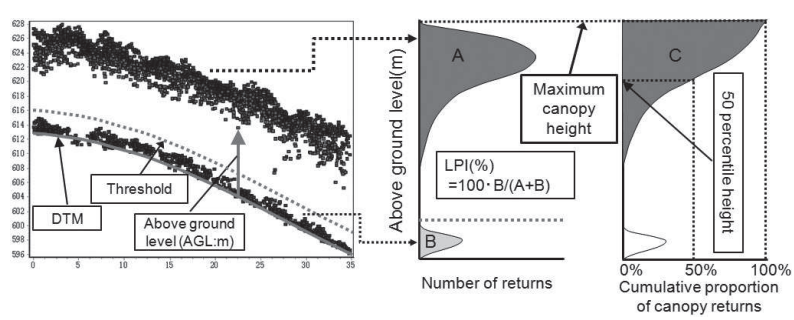

Fig. 11 Overview of canopy height percentile and laser penetration index (LPI).

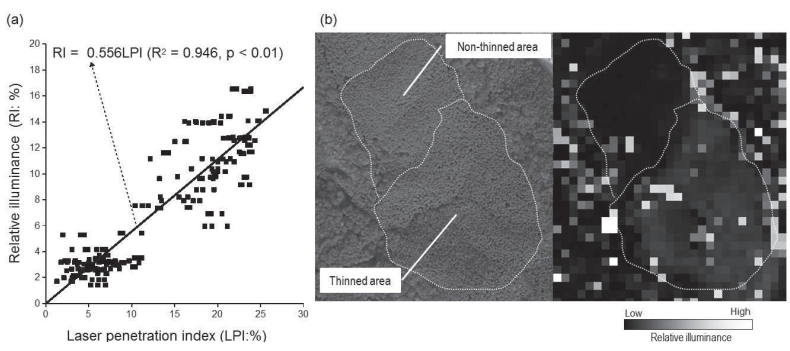

Fig. 12 Relationship between laser penetration index (LPI:\%) and relative illuminance (RI: \%) within forest (a) and difference of RI estimated by LPI in thinned and non-thinned forest area (b). 
度 (RI: \%) と, その測定地点におけるLPIの関係を示した ものである。この関係を用い, 間伐実施区と隣接する未 実施区のRI空間分布を算出すると Fig. 12(b)のように両 区の差異が明確となる。これにより, 間伐等の森林管理 状態を広域かつ迅速に評価できる可能性が示唆された。

\section{5. まとめ}

本稿では，航空機LiDARによる森林計測手法について 解説した。航空機LiDARは従来のリモートセンシング技 術とは異なり, 高さに関する絶対的かつ精度の高い情報 をもたらす有用な技術である。 今後, 機器及び解析技術 の高度化とともに，その観測コストが改善されれば，森 林情報取得の標準的な技術となることも十分に考えられ るであろう。

\section{謝 辞}

本研究の一部はJSPS科研費 24580217 , 災害に強い森 林づくり推進事業 (三重県), 及び戦略的創造研究推進事 業CRESTの助成を受けたものである。

\section{参考文献}

1）竹島 喜芳，森＼cjkstart勝：写真測量とリモートセンシング4 (2005) 44.

2) 松本 光郎：森林リモートセンシング第3版 (日本林業調査 会, 2010) 282 .

3）村上拓彦, 番場 和德, 望月翔太: 森林計画学会誌 47 (2013) 83

4）藤野 正也：農業と経済 2013.12 (2013) 31.

5）田口仁・臼田 裕一郎・福井弘道・古川邦明：日本リモー トセンシング学会誌 27 (2007) 109.

6）夏井 雄一郎：現代林業 2014.10 (2014) 40.

7) 佐々木 剛：景観生態学 17 (2012) 43.

8）横尾 泰宏：フォレストコンサル 137 (2014) 17.
9) 平田 泰雅 : 森林計画学会誌 39 (2005) 81 .

10) 平田 泰雅：森林計画学会誌 41 (2007) 1.

11) S. E. Reutebuch, H-E. Andersen, and R. J. McGaughey: J. For. 103 (2005) 286.

12) M. A. Wulder, C. W. Bater, N. C. Coops, T. Hilker, and J. C. White: For. Chronicle 84 (2008) 807.

13) J. Hyyppä, H. Hyyppä, D. Leckie, F. Gougeon, X. Yu, and M. Maltamo: Int. J. Remote Sens. 29 (2008) 1339.

14) J. Peuhkurinen, L. Mehtätalo, and M. Maltamo: Can. J. For. Res. 41 (2011) 583.

15) 大野勝正：森林科学 74 (2015) 9.

16）高橋 與明, 粟屋 善雄, 田中真哉：九州森林研究 66 (2013) 6.

17) E. H. Hansen, T. Gobakken, and E. Næsset: Rem. Sens. 7 (2015) 8453.

18) M. K. Jakubowski, Q. Guo, and M. Kelly: Rem. Sens. Environ. 130 (2013) 245

19) J. Hyyppä and M. Inkinen: Photogramm. J. Finland 16 (1999) 27.

20) T. Takahashi, K. Yamamoto, Y. Senda, and M. Tsuzuku: J. For. Res. 10 (2005) 305.

21）松英恵吾, 伊藤 拓弥, 内藤 健司：写真測量とリモートセ ンシング 47 (2008) 26.

22）伊藤 拓弥, 松英 恵吾, 執印 康裕, 内藤 健司：写真測量と リモートセンシング 50 (2011) 18

23) X. Liu: Progress in Physical Geography 32 (2008) 31.

24) A. S. Maguya, V. Junttila and T. Kauranne: ISPRS J. Photogram. Rem. Sens. 85 (2013) 74.

25) C. Véga, S. Durrieu, J. Morel, and T. Allouis: Computers \& Geosciences 44 (2012) 31.

26) T. Takahashi, K. Yamamoto, Y. Senda, and M. Tsuzuku: J. For. Res. 11 (2006) 117.

27) L. Wang, A. G. Birt, C. W. Lafon, D. M. Cairns, R. N. Coulson, M.D. Tchakerian, W. Xi, S. C. Popescu, and J. M. Guldin: Geoinformatica 17 (2013) 35.

28) T. Takahashi, K. Yamamoto, Y. Senda, and M. Tsuzuku: J. For. Res. 10 (2005) 135.

29) 松英 恵吾, 伊藤 拓弥, 内藤 健司 : 写真測量とリモートセ ンシング 45 (2006) 4.

30) D. Riaño, F. Valladares, S. Condés, and E. Chuvieco: Agr. For. Meteor. 124 (2004) 269.

31) 小谷英司, 粟屋 善雄 : 写真測量とリモートセンシング 52 (2013) 44.

32) K. Yamamoto, T. Takahashi., Y. Miyachi, N. Kondo, S. Morita, M. Nakao, T. Shibayama, Y. Takaichi, M. Tsuzuku, and N. Murate: J. For. Res. 16 (2011) 425. 